\title{
Memahami Konsepsi "Kafir" pada Organisasi Keagamaan Nahdlatul Ulama (NU) dan Muhammadiyah di Media Sosial
}

\author{
Abdul Wahid, Fariza Yuniar Rakhmawati ${ }^{2}$, Nia Ashton Destrity ${ }^{3}$ \\ Universitas Brawijaya, Jl. Veteran Malang, Jawa Timur 65145 \\ *e-mail : wahidjumaizah@ub.ac.id
}

\begin{abstract}
Radicalism appears and develops in different social settings. In Asia, radicalism appears in the form of religious group identity such as Extreme Buddhism in Burma, the extreme Hindu in India, and Muslim militants in the Middle East and Asia, including Indonesia. In its development, radicalism emits in the form of labeling such as "kafir" that bring consequences to discrimination, especially in non-Muslim groups. This article seeks to uncover the construction of "kafir" on Nahdlatululama and Muhammadiyah Twitter accounts during March 2019 through Saussure's structural semiotics approach. Text and visual content are identified based on semiotic systems (such as socio-cultural practices) and structural relationships between texts (opposition, correlation and logical relationships). The research shows that NU and Muhammadiyah have different constructions on the term "kafir". NU agreed that there are two different contexts in the use of the term, namely in the context of faith (religion) and the context of the State. NU recommends to eliminate the use of "kafir" for non-Muslims and replace them with the term Muwathinun (citizen) in the context of national and state life. Unlike NU, Muhammadiyah emphasized that the use of the term has tendency to refer to non-Muslims. "Kafir" should not be eliminated in Islamic teachings, but the social context should be used wisely. Communication became a central intermediary in the discourse on identity politics in Indonesia.
\end{abstract}

Keywords: Kafir, social media, Muhammadiyah, Nahdlatul Ulama, radicalism

\begin{abstract}
ABSTRAK
Radikalisme muncul dan berkembang di latar sosial berbeda. Di Asia, radikalisme muncul dalam bentuk identitas kelompok agama seperti ekstrem Buddha di Myanmar, ekstrem Hindu di India, dan militan Muslim di Timur Tengah dan Asia, termasuk Indonesia. Pada perkembangannya, radikalisme mewujud dalam bentuk pelabelan seperti "kafir" yang membawa konsekuensi pada diskriminasi, terutama pada kelompok non-muslim. Artikel ini berupaya untuk mengungkap konstruksi "kafir" pada unggahan akun Twitter @nahdlatululama dan @muhammadiyah selama Maret 2019 melalui pendekatan semiotika struktural Saussure. Konten berupa teks dan visual diidentifikasi berdasarkan sistem semiotik (seperti praktik socio-kultural) dan relasi struktural antar teks (oposisi, korelasi dan relasi logis). Hasil riset menunjukkan bahwa organisasi Islam NU dan Muhammadiyah memiliki konstruksi berbeda terhadap istilah "kafir". NU menyepakati bahwa terdapat dua konteks yang berbeda dalam penggunaan istilah "kafir", yaitu dalam konteks keimanan (agama) dan konteks bernegara. NU merekomendasikan untuk menghilangkan penggunaan istilah "kafir" bagi non-muslim dan menggantinya dengan istilah muwathinun (warga negara) dalam konteks kehidupan berbangsa dan bernegara. Berbeda dengan NU, Muhammadiyah menekankan bahwa penggunaan istilah "kafir" memiliki kecenderungan merujuk kepada non-muslim. Istilah "kafir" tidak boleh dihilangkan dalam ajaran Islam, namun penyebutan "kafir" perlu digunakan secara bijak. Komunikasi menjadi perantara sentral dalam diskursus tentang politik identitas di Indonesia.
\end{abstract}

Kata kunci: konstruksi kafir; media sosial; Muhammadiyah; Nahdlatul Ulama, radikalisme 


\section{Latar Belakang}

Aksi bom bunuh diri di Surabaya pada 2018 dan Sibolga awal Maret 2019 lalu menunjukkan radikalisme masih dekat dengan kekerasan. Peristiwa bom bunuh diri ini melengkapi sejumlah kejadian bom bunuh diri di Indonesia dalam beberapa tahun belakangan; bom bunuh diri di Jl. MH Thamrin Jakarta pada 2016 dan bom Bali I dan Bom Bali II pada awal 2000-an. Rentetan peristiwa bom bunuh diri tersebut menjadi gejala bagaimana paham radikal masih hidup di masyarakat. Radikalisme tidak hanya dilatari oleh agama, tapi juga paham lain seperti supremasi kulit putih di Eropa.

Peristiwa penembakan di masjid Al Noor dan Linwood yang terjadi di Selandia baru pertengahan Maret 2019 lalu merupakan tanda kecenderungan peningkatan pemahaman radikalisme global. Latar pembunuhan ini diakibatkan oleh sentimen kulit putih terhadap pendatang, terutama imigran muslim ke beberapa negara eropa. Orang kulit putih menganggap, para imigran justru menjadi ancaman dan dapat meminggirkan keberadaan orang eropa. Parahnya, media sosial Facebook digunakan untuk menyiarkan secara langsung peristiwa penembakan ini selama 17 menit.

Radikalisme muncul dan berkembang di latar sosial berbeda. Radikalisme di Amerika Serikat dan beberapa negara Eropa lebih banyak terkait dengan kelompok white supremacist yang memiliki keyakinan mereka merasa lebih berhak atas negara daripada kelompok lainnya. Di Asia, radikalisme muncul dalam bentuk identitas kelompok agama seperti ekstrem Buddha di Myanmar, ekstrem Hindu di India, dan militan Muslim di Timur Tengah dan Asia, termasuk Indonesia. Dua peristiwa di atas menunjukkan, radikalisme dalam puncak ekspresi ekstrimnya, telah mengarah pada aksi terorisme dan pembunuhan massal.

Dalam konteks Indonesia, radikalisme sering dikaitkan dengan fundamentalisme, militant, dan Islamis. Istilah tersebut berhubungan dengan keyakinan mendirikan negara berbasis agama, dengan atau tanpa kekerasan (Vedy R. Hadiz, 2008). Van Bruinessen (2002) melihat radikalisme di Indonesia berakar jauh dari Masyumi dan Darul Islam sebelum berubah bentuk pada 1980 dan akhir pemerintah Soeharto. Radikalisme bukan hanya selalu terkait dengan agama, tetapi juga pada bentuk pemikiran tunggal yang menganggap benar keyakinannya sendiri dan menyalahkan kelompok lain (Wahid, A., 2020). Salah satu penyumbang menguatnya radikalisme adalah politik populisme, mediasi konten kekerasan di media sosial, streotype terhadap minoritas dan kecenderungan kelompok mayoritas menuntut privilese atas posisinya sebagai mayoritas (Wahid, A. Destitry, N.A., Rakhmawati, F.Y., 2020; Jainuri, A., 2016).

Peningkatan tindak kekerasan berbasis agama juga tercatat meningkat. Hasil survey Wahid Institute pada 2016 menyebutkan, terjadi peningkatan jumlah peristiwa tindak kekerasan atas nama agama dalam tiga tahun terakhir. Peristiwa pelanggaran beragama dan berkeyakinan pada 2016 tercatat sebanyak 204 peristiwa dengan 315 tindakan. Jumlah ini naik $7 \%$ dari tahun 2015 yang dilaporkan sebanyak 190 peristiwa dengan 249 tindakan dan pada 2014 tercatat sebanyak 158 peristiwa. Hasil riset Setara Institute (2012) juga menyebutkan, terdapat 216 kasus serangan terhadap minoritas agama pada 2010, 244 kasus pada 2011, dan 264 kasus pada 2012. Laporan Komnas HAM mencatat bahwa selama 2016, pengaduan atas pelanggaran kebebasan beragama di Indonesia berjumlah 97, meningkat dari 87 kasus pada 2015 (Adam, 2017). Survei Setara Institute menunjukkan selama tahun 2018, terjadi 160 peristiwa pelanggaran kebebasan beragama dan berkeyakinan di 25 provinsi di Indonesia (Rachman, 2019). 
Studi International NGO Forum on Indonesian Development (INFID) dan jaringan GUSDURian pada unggahan media sosial menyebutkan, terdapat beberapa kata kunci yang diidentifikasi menjadi pintu masuk radikalisme; antara lain kata kafir, sesat, syariat Islam, tolak demokrasi, jihad, antek asing, komunis, liberal, pengkhianat agama, dan musuh Islam. Riset tersebut menemukan dua kata kunci terbanyak yaitu kata kafir dengan 5.173 kicauan dan komunis 995 kicauan dalam sebulan (Saroh, 2017).

Studi Wahid, A (2020) menyebutkan, penyebutan kafir dalam hubungan sosial dipahami dalam konteks gurauan. Dalam konteks politik, penyebutan kafir dapat melahirkan tindakan diskriminatif terutama ketika dihubungkan dengan organisasi dan gerakan konservati. Studi lain yang dilakukan oleh LIPI menunjukkan bahwa ujaran kebencian dapat ditandai dengan bentuk-bentuk ujaran yang merendahkan dan meliyankan kelompok lain yang dianggap berbeda serta sejumlah ujaran kebencian muncul dengan sistematis dibuat oleh kelompok sosial tertentu untuk menciptakan narasi negatif yang telah berimplikasi pada dekonstruksi makna dan semangat kebangsaan (LIPI, 2018).

Hasil riset tersebut seolah mengarahkan pada anggapan bahwa tindak kekerasan masih dianggap sebagai bentuk perjuangan karena dalam setiap gerakannya selalu menggunakan simbol-simbol Islam. Simbol-simbol agama digunakan untuk membedakan satu kelompok dengan kelompok lain. Penggunaan simbol agama seringkali ditafsirkan secara tunggal. Dengan kata yang lain, penggunaan kata kafir, bid'ah, serta sesat sering ditemukan pada kelompok yang menafsirkan agama secara sempit. Dirga Maulana (2017) menyebut penafsiran sempit pada teks secara skriptual dan ekslusif dapat meningkatkan radikalisme di Indonesia.
Radikalisme juga mendapatkan tempat secara masif melalui penggunaan media sosial dan awamnya literasi masyarakat terhadap agama, terutama yang termediasi melalui media sosial. Beberapa kasus kekerasan yang berlatar agama di Indonesia diawali oleh tudingan satu kelompok pada kelompok lain, terutama dari mayoritas pada minoritas. Tudingan ini menjadi pemicu ketegangan dan konflik antar penganut keyakinan di Indonesia, terutama dikotomi antara muslim-non muslim. Jika terdapat perbedaan cara beribadah, seringkali dilabeli sebagai pelaku bid'ah bahkan kafir. Padahal, aktivitas penyebaran agama tidak dapat dilepaskan dari konteks kebangsaan. Dalam kehidupan berbangsa, selalui didasari oleh semangat perdamaian, toleransi, dan keadilan pada kelompok yang berbeda sekalipun.

Beberapa organisasi masyarakat (Ormas) keagamaan menaruh perhatian serius pada perkembangan radikalisme dengan mengidentifikasi penggunaan simbol agama. Organisasi keagamaan terbesar di Indonesia, Nahdlatul Ulama (NU) pada dua tahun terakhir mendiskusikan masalah radikalisme dalam Musyawarah Nasional (Munas). Pada Munas NU 2019, NU memberikan rekomendasi untuk mengganti penggunaan kata "kafir" menjadi muwathinun untuk mendefinisikan kelompok non-muslim di Indonesia. Alasannya adalah penyebutan kata "kafir" pada kelompok nonmuslim dianggap sebagai bentuk diskriminasi dalam kehidupan berbangsa. Muhammadiyah juga turut menggunakan istilah kafir. Sebagai dua organisasi keagamaan terbesar di Indonesia, penggunaan istilah kafir dalam berbagai platform yang digunakan oleh dua organisasi tersebut tentu punya dampak pada pemaknaan kafir di masyarakat. Terlebih, dua organisasi ini dianggap masih kalah pamor dengan pewacanaan islam populer yang menyasar perhatian generasi muda, dibanding dengan akun-akun dengan kecenderungan radikal. 
Tulisan ini berupaya untuk mengungkap konstruksi "kafir" oleh NU dan Muhammadiyah melalui media sosial sebagai medium diseminasi gagasan mereka. Sebagaimana dikatakan Ahyar (2017), fenomena proliferasi gerakan Islam dalam bentuk kliktivism terhubung dengan perjalanan demokrasi di Indonesia. Studi ini dilakukan untuk menggali bagaimana "kafir" sebagai kata yang dianggap identik dengan konten radikal yang disebarkan melalui perantara media sosial di NU dan Muhammadiyah.

\section{a. Nahdlatul Ulama (NU) dan Muhammadiyah sebagai Organisasi Islam di Indonesia}

Nahdlatul Ulama (NU) merupakan salah satu organisasi Islam besar di Indonesia. NU menganut pemahaman Ahlussunah Wal Jamaah sebagai pemikiran tengah antara rasionalis (ekstrem aqli) dengan skripturalis (ekstrem naqli) yang tidak hanya menggunakan Al Ouran dan Sunnah sebagai sumber pemikiran tetapi juga disertai dengan kemampuan berakal dan realitas empiris ("NU Online | Suara Nahdlatul Ulama," 2015). Berangkat dari pola berpikir yang demikian, para penggagas organisasi ini beranggapan bahwa Islam sebagai nilai kehidupan dapat diterapkan bersama dengan budaya atau tradisi lokal masyarakat. NU tidak memaksakan implementasi nilai Islam secara murni yang menilai penyesuaian Islam dengan tradisi lokal sebagai bid'ah. NU menerima dan mengasimilasi tradisi lokal dengan nilai-nilai Islam, sehingga masyarakat pribumi tidak merasa meninggalkan nilai budaya mereka ketika memeluk dan mempraktikkan ajaran Islam (Ali, 2017). Hal ini memperkuat pernyataan bahwa meskipun NU jelas sebagai organisasi Islam dan mendeklarasikan sebagai Islam ala ahlussunah wal Jamaah tetapi ciri keislaman tersebut tetap berkonteks Indonesia, tempat gerakan NU dibangun (Suaedy, 2009).
NU menerjemahkan pemikiran mereka dalam beragam upaya untuk menghidupkan kembali gerakan pribumisasi Islam sebagaimana diwariskan oleh Walisongo dan para pendahulu, mempelopori perjuangan kebebasan bermadzhab di Mekkah sehingga umat Islam di dunia dapat menjalankan ibadah sesuai dengan madzhab masing-masing, dan mempelopori gerakan Islam kultural dan penguatan masyarakat sipil di Indonesia, serta menegakkan ajaran Islam berdasarkan pemahaman Ahlussunah Wal Jamaah di tengah kehidupan masyarakat di dalam wadah Negara Kesatuan Republik Indonesia (NKRI) ("NU Online | Suara Nahdlatul Ulama," 2015). NU hadir sebagai organisasi Islam moderat di Indonesia yang menerima tradisi lokal dan beradaptasi dengan perubahan zaman sesuai dengan semboyan Almuhafadhoh alal qodimis solih wal akhdu bil jadidil aslah (memelihara yang lama yang baik dan mengambil yang baru yang lebih baik) (Ali, 2017).

NU tidak mempertentangkan antara kebangsaan dan keislaman seperti praktik di Indonesia dimana NU bersikap terbuka terhadap keberagaman, menerima Pancasila sebagai dasar negara, dan tidak menuntut syariat Islam diterapkan secara formal sebagaimana prinsip yang telah ditetapkan yaitu tawasut (moderat), tasamuh (toleran), tawazun (proporsional) dalam merespon berbagai persoalan sehingga tidak terjebak dalam sikap radikal atau ekstrem (tathorruf) (Ali, 2017). NU bergerak dalam bidang keagamaan dan kemasyarakatan serta dibentuk dengan tujuan memahami dan mengamalkan ajaran Islam baik dalam konteks komunikasi vertikal dengan Allah SWT maupun komunikasi horizontal dengan sesama manusia (Raditya, 2019). Ketua Umum Majelis Dzikir Hubbul Wathan, K.H. Musthofa Aqil Siroj, pada acara Silaturrahmi Kebangsaan dan Tabligh Akbar di Kabupaten Padang Pariaman Sumatera Barat menjelaskan bahwa perintah Allah kepada Nabi 
Muhammad SAW diawali bukan dengan menyebut nama Allah langsung, melainkan tiga kali turun perintah secara berturut-turut melalui surat Al-Alaq, Al-Mudasir, dan Al-Muzammil yang menyebut kata Rab (Tuhan Semesta Alam), baru selanjutnya surat keempat Al-Fatihah dengan kata Allah, hal tersebut menunjukkan bahwa Nabi Muhammad SAW diperintahkan memandang semua sebagai makhluk Allah dan tidak diperintah hanya untuk umat Islam, sehingga dalam berinteraksi dengan orang lain kita tidak boleh melihat agama atau suku tetapi sebagai sesama manusia harus berbuat baik (Tanjung \& Muiz, 2019).

Selain NU, organisasi Islam yang juga tumbuh dan berkembang di Indonesia adalah Muhammadiyah. Muhammadiyah merupakan gerakan Islam yang memiliki keyakinan bahwa Islam adalah agama Allah yang diturunkan sebagai hidayah dan rahmat kepada manusia, sehingga dalam menerapkan ajaran Islam berdasarkan pada Al Quran dan Sunnah Rasul ("Matan Keyakinan dan Cita-cita Hidup Muhammadiyah Pimpinan Pusat Muhammadiyah," 1997). Sebagaimana pandangan pendiri Muhammadiyah, K.H. Ahmad Dahlan, gerakan modern Islam ini cenderung mengarah pada pemurnian ajaran Islam dengan Al Quran dan Sunnah Nabi yang otentik sebagai landasan pokok serta menolak setiap bentuk takhayul, bid'ah, dan khurafat dalam aqidah dan ibadah (Maarif, 2006).

Muhammadiyah juga disebut sebagai gerakan tajdid yang bermakna pembaruan, Muhammadiyah berupaya memperbarui pengertian kaum Muslimin tentang agama mereka, mencerahkan hati dan mencerdaskan pemikiran dengan jalan mengenalkan kembali ajaran Islam dengan dasar Al Quran dan Sunnah (Maarif, 2006). Muhammadiyah berupaya menerapkan ajaran Islam mencakup bidang aqidah (menegakkan aqidah Islam yang murni, bersih dari gejala kemusyikan, bid'ah, dan khurafat tanpa mengabaikan prinsip toleransi sesuai ajaran Islam), akhlak (menegakkan nilainilai akhlak mulia dengan mengacu pada ajaran Al Quran dan Sunnah tidak pada nilai-nilai buatan manusia), ibadah (menegakkan ibadah sesuai tuntunan Rasulullah SAW tanpa tambahan dan perubahan dari manusia), muamalah duniawiyah (pembinaan masyarakat berdasar pada ajaran agama serta menjadikan seluruh kegiatan dalam bidang sebagai ibadah kepada Allah SWT) ("Matan Keyakinan dan Citacita Hidup Muhammadiyah | Pimpinan Pusat Muhammadiyah," 1997). Tidak jauh berbeda dengan NU, Muhammadiyah juga menerima Pancasila sebagai dasar negara Indonesia. NU dan Muhammadiyah menjadikan Pancasila sebagai dasar negara yang dinilai tidak bertentangan dengan Islam (Wahid, Rakhmawati, \& Destrity, 2016).

Pada dasarnya NU dan Muhammadiyah memiliki pandangan yang sama terhadap relasi antara agama dan negara. NU dan Muhammadiyah melihat negara sebagai mekanisme pengaturan agama yang rasional (Wahid, Rakhmawati, \& Destrity, 2016). Kedua organisasi Islam modernis ini menyebarkan gagasan mereka melalui media antara lain NU dengan NUOnline dan Muhammadiyah dengan Matan. Gagasan gerakan NU melalui NUOnline berupaya mewacanakan gerakan Islam melalui pendekatan tradisi atau kultural, sedangkan Matan selalu mempromosikan gerakan Islam melalui cara-cara modern melalui negara sekaligus membatasi percampuran antara Islam dengan tradisi kultur lokal (Wahid, Rakhmawati, \& Destrity, 2016).

\section{b. Media Sosial sebagai Platform Diseminasi Gagasan}

Media menjadi kebutuhan manusia untuk memenuhi kebutuhan hidup atas informasi. McLuhan (2016) menyatakan media merupakan perpanjangan alat indera manusia. Media juga 
membantu manusia menafsirkan kehidupan sosial. Terdapat empat era komunikasi yang disebutkan McLuhan era terakhir adalah era elektronik yang juga mencakup teknologi internet. Media online menjadi perpanjangan seluruh indera karena memfasilitasi terjadinya konvergensi media yang menggabungkan media cetak, audio juga visual.

Media online menjanjikan ruang kesetaraan antar pengguna untuk dapat mempresentasikan diri dan mengartikulasi gagasan. Croteau (2000) menjelaskan media baru menjadi benih budaya demokrasi baru dimana terdapat sirkulasi makna alternatif dan terjadi pola komunikasi antar warga negara sehingga memungkinkan tingginya partisipasi komunikasi publik. Di media baru berkembang forum-forum bagi perkembangan kelompok kepentingan dan pembentukan opini (McQuail, 2011). Media baru membagikan kuasa informasi yang awalnya dimiliki penguasa sumber daya informasi kepada tiap diri warga negara sehingga setiap orang memiliki kesempatan akses yang lebih besar.

Lister (2009) menambahkan media baru menyediakan ruang cukup untuk demokrasi partisipatoris dan perdebatan juga voting. Media baru memiliki karakteristik interaktivitas yang berada di antara karakteristik media massa dan komunikasi tatap muka. Penerima pesan melalui media baru tidak hanya dapat menerima pesan tapi juga merespon pesan yang diterima, menyeleksi pesan yang ingin diterima dan mengirim pesan mereka sendiri.

Media sosial yang termasuk dalam collective participatory media di media baru memberikan penghargaan pada setiap gagasan sehingga di media sosial lebih berpotensi terwujud percakapan yang lebih plural. Kaplan dan Haenlein mendefinisikan media sosial sebagai aplikasi berbasis internet yang dibangun atas pondasi ideologis dan teknologi web 2.0 dan memungkinkan terjadinya produksi dan pertukaran User Generated Content (Treem \&
Leonardi, 2013). Howard dan Parks menawarkan definisi yang lebih kompleks mengenai media sosial yang terdiri dari tiga bagian yaitu (1) infrastruktur dan peralatan informasi yang digunakan untuk memproduksi dan mendistribusikan konten, (2) konten digital berupa pesan personal, berita, ide, dan produk kultural, dan (3) orang, organisasi, dan industri yang memproduksi dan mengonsumsi konten digital (Carr \& Hayes, 2015). Orang-orang yang memiliki pandangan ekstrim dan berbeda dari opini publik memperoleh wadah ekspresi di media sosial. Mereka berani mengutarakan gagasan yang mengarah pada adu argumen bahkan berakhir dengan kekerasan verbal (Agbasiere, 2018).

Kebebasan di media sosial terbangun karena terbatasnya aturan yang dapat mengikat media baru. Terdapat kesetaraan yang lebih besar untuk pengguna, penerima, penonton atau partisipan dalam jaringan komunikasi pada media baru. Media baru memberikan kesempatan pada 'khalayak' untuk sekaligus menjadi 'penulis' dan 'gatekeeper'. Berbeda dengan media massa yang memberikan peranan berbeda antara 'khalayak', 'penulis' dan 'gatekeeper'. Peran 'khalayak' adalah menerima pesan media, sedangkan peran 'penulis dipegang oleh jurnalis dan 'gatekeeper' dipegang oleh editor. Bagaimanapun internet tidak memiliki status kelembagaan yang jelas dan tidak dimiliki, dikontrol, atau diatur oleh satu lembaga tertentu, tetapi hanya merupakan jaringan yang terhubung secara internasional dan beroperasi menurut aturan tertentu (McQuail, 2011). Kebebasan berpendapat di media sosial kemudian diatur secara global melalui Social Media Guidebook yang dikompilasi RfoM pada 2013, berfokus pada self regulation (Benedek \& Kettemannn, 2013).

Kemudahan akses media sosial melalui telepon seluler mendukung produksi juga pertukaran wacana antar individu. Media sosial 
memberikan ruang informasi pada publik secara bebas sekaligus fasilitasi pertukaran pesan di media sosial melalui jejaring antar pengguna. Pengguna media sosial dapat bertukar informasi, gagasan dan pengalaman, serta untuk mengembangkan hubungan pribadi yang aktif di media sosial didukung oleh teknologi web 2.0, yakni teknologi untuk kolaborasi dan berbagi data antara individu pengguna internet (Straubhaar, 2012).

\section{c. Semiotika Struktural dan Konstruksi bahasa}

Secara literal, analisis struktural yang kembali ke saussure sering menyamakan parole dengan teks; sebuah bentuk untuk membuat kesimpulan tentang kode atau langue. Metaphor ini menunjukkan, "langue" merupakan abstrak eksistensi di balik teks. Dengan demikian, langue memiliki potensi yang mengatur bentuk (Strozier, R., M. 2012)

Saussure sebenarnya menempatkan analisisnya dalam batas kesadaran. Langue ada dalam individu atau kelompok kesadaran; tanda adalah "Une entité psikique à Deux faces" atau entitas dua sisi psikis; Parole juga memiliki karakter ini dari interioritas, terletak seperti di bagian psikologis-eksekutif dari sirkuit wicara. Strozier (2012) mengatakan, bentuk, merupakan "ide" dalam pikiran seseorang yang berkaitan dengan expresi umum untuk membedakan yang tunggal dari yang jamak. Bentuk ini, yang juga disebut esensi, menjadi bagian tetap yang tersedia pada setiap tahap langue, untuk menghasilkan pembedaan tunggal/jamak yang kongkret, yakni apa yang muncul di sini sebagai unit referensial yang terpisah.

Sebuah konsep memiliki makna karena adanya hubungan atau relasi antar tanda. Hubungan dasar tanda selalu bersifat oposisi. Saussure (1959: 120) mengatakan, "Dalam bahasa hanya ada perbedaan," Jadi, "kaya" tidak berarti apa-apa kecuali ada "miskin," atau "bahagia" kecuali ada "sedih." Menurut Saussure, konsep merupakan satu hal yang murni diferensial dan tidak ditentukan secara positif oleh esensi (content), tetapi secara negatif ditentukan oleh hubungan mereka dengan istilah lain dari sistem. Bukan "konten" yang menentukan makna, tetapi "hubungan" dalam beberapa jenis sistem. Saussure menambahkan, "Tanda berfungsi, bukan melalui nilai intrinsik mereka tetapi melalui posisi relatif mereka" (Saussure, 1959: 118).

Cara kerja penandaan ini tidak hanya berlaku pada bahasa, tetapi juga berlaku untuk teks secara umum. Tidak ada yang memiliki makna dalam dirinya sendiri. Penandaan dalam Semiotika structural Saussure selalu mengandaikan oposisi biner. Menurut Strozier (2012), dalam semiotika, oposisi pada tanda memiliki arti bahwa konsep-konsep yang berlawanan harus terkait dalam beberapa cara. Selalu ada beberapa topik (tidak selalu disebutkan) yang menghubungkan mereka. Keterhubungan ini dapat membentuk atau mengkonstruksi makna berdasarkan relasi atar tanda pada bahasa. Konstruksi sosial mendiskusikan hubungan antara level mikro dan makro dimana analisis pada level mikro (kata, gambar, tindakan) dilakukan untuk menjelaskan proses makro (struktur, institusi) (S. Littlejohn \& Foss, 2009).

\section{Metode}

Penelitian ini dilakukan dengan metode semiotika struktural Saussure. Semiotika merupakan ilmu tentang tanda. Analisis struktural berfokus pada relasi struktural dalam sistem penandaan di suatu momen yang spesifik. Sistem signifikasi termasuk identifikasi sistem semiotik (seperti praktik socio-kultural) dan relasi struktural antar teks (oposisi, korelasi dan relasi logis). 
Penelitian ini dilakukan pada unggahan akun Twitter @nahdlatululama dan @muhammadiyah selama periode bulan Maret 2019. Data yang telah didokumentasikan selanjutnya dipilih berdasarkan kata kunci "kafir". Konten berupa teks dan visual dianalisis secara bersamaan.

Teknik analisis data dalam penelitian ini disusun dengan mengadopsi teknik analisis data dalam metode penelitian semiotika strukturalis Saussure (Chandler, 2002): (a) Memeriksa secara rigid tanda-tanda yang relevan dengan "kafir" pada objek penelitian (b) membedah elemen tanda yang digunakan oleh produsen pesan dan mencari hubungan asosiatif pada relasi signifiersignified, (c) menafsirkan arti tanda-tanda tersebut dari melalui pembedaan binari (d) Menghubungkan makna dalam relasi antar tanda melalui aspek synchronic. (e) Menafsirkan makan dari relasi antar tanda dalam teks yang dianalisa.

\section{Pembahasan}

\section{a. "Kafir": Konsep, Bentuk, dan Asosiasi Penggunaannya}

"Kafir" sebagai sebuah konsep yang tetap dalam teologi keagamaan, terutama Islam tidak dapat dipisahkan dari bagaimana penggunaannya dalam bentuk penandaan yang berbeda. Konsep (signified) dan bentuk (signifier) merupakan basis pemaknaan atas realitas sosial. Relasi internal dalam struktur bahasa ini hanya dapat dimungkinkan jika dihubungkan dengan hal yang lain. Muhammadiyah melalui cuitan akun @muhammadiyah dan Nahdlatul Ulama (NU) melalui @nahdlatululama sama-sama menggunakan konsep "kafir" sebagai acuan tanda yang diwujudkan secara berbeda.

Cuitan di akun Twitter @muhammadiyah, pada tanggal 3 Maret 2019, berisikan berita dari website Muhammadiyah dengan judul "Terkait Polemik Penghapusan Istilah Kafir, Berikut Tanggapan Din Syamsuddin". Berita tersebut berisi penjelasan Din Syamsudin yang menjabat sebagai Ketua Dewan Pertimbangan Majelis Ulama Indonesia (MUI) dan Ketua Umum Pimpinan Pusat Muhammadiyah periode 20052010 dan 2010-2015. Muhammadiyah turut mengomentari konsep "kafir" sebagai respon terhadap Putusan Musyawarah Nasional (Munas) Nahdlatul Ulama pada 1 Maret 2019 yang memperdebatkan penggunaan istilah kafir di masyarakat.

Penyebutan "kafir" dalam artikel yang diunggah, selalu merujuk pada konsep kafir sebagaimana yang telah dijelaskan dalam definisi baku yang terdapat pada Al-Qur'an dan Hadits. Konsep kafir oleh Din, diwujudkan dalam bentuk bahasa seperti muslim tak beriman, kafir, musyrik, fasik, orang berbeda keyakinan, nonmuslim, dan penggunaan yang tak dapat diubah. Bentuk Bahasa (signifier) sebagai perwakilan konsep kafir (signified) hanya dapat dipahami saat dihubungkan dengan bentuk yang lain. Musyrik misalkan, hanya dapat dihubungkan dengan keyakinan dalam akidah Islam dan dapat dimaknai sebagai "kafir" karena bertolak belakang dengan ciri-ciri mukmin.

Tabel 1 Konsep, bentuk, dan asosiasi penggunaan "kafir" oleh Muhammadiyah

\begin{tabular}{|c|c|c|c|}
\hline \multicolumn{4}{|c|}{ Kafir } \\
\hline Signified & Signifier & $\begin{array}{l}\text { Relasi } \\
\text { asosiatif }\end{array}$ & Oposisi \\
\hline \multirow[t]{6}{*}{$\begin{array}{l}\text { Konsep } \\
\text { kafir }\end{array}$} & $\begin{array}{l}\text { Muslim tak } \\
\text { beriman } \\
\text { Kafir, } \\
\text { Musyrik, } \\
\text { Fasik }\end{array}$ & $\begin{array}{l}\text { keyakinan } \\
\text { dalam } \\
\text { akidah Islam }\end{array}$ & Mukmin \\
\hline & $\begin{array}{l}\text { Orang } \\
\text { berbeda } \\
\text { keyakinan } \\
\text { The other } \\
\text { The } \\
\text { outsider }\end{array}$ & $\begin{array}{l}\text { teologi } \\
\text { antar- } \\
\text { agama }\end{array}$ & $\begin{array}{l}\text { Keyakinan } \\
\text { sama } \\
\text { The } \\
\text { Insider }\end{array}$ \\
\hline & $\begin{array}{l}\text { Non- } \\
\text { muslim }\end{array}$ & Kebangsaan & Muslim \\
\hline & $\begin{array}{l}\text { Tidak } \\
\text { diubah }\end{array}$ & Akidah & Diganti \\
\hline & Toleransi & Relasi sosial & Intoleransi \\
\hline & Peyoratif & Relasi sosial & Kesamaan \\
\hline
\end{tabular}




\begin{tabular}{ll}
\hline & (memperb \\
uruk)
\end{tabular}

Dalam konteks teologi agama Islam, Din Syamsudin mengatakan bahwa istilah "kafir" juga dapat disematkan kepada mereka yang beragama Islam. la mengatakan "Kita ini mukmin beriman, ada yang tidak beriman sesuai Islam disebut oleh Al Qur'an dengan kata kafir, musrik, juga fasik,". Artinya, seseorang yang tidak menjalankan keimanan Islam sesuai dengan ajaran Islam adalah kafir. Hal ini dikarenakan pernyataan tersebut telah ada di dalam Al Quran. Dalam hal ini, "kafir" dimaknai sebagai non-muslim, seseorang beragama Islam yang tidak beriman sesuai ajaran Islam, serta seseorang yang berbeda keyakinan.

Istilah "kafir" juga digunakan dalam teologi keagamaan lain untuk menyebut seseorang yang berbeda keimanan dari penganut agama yang lain secara umum. Menurutnya, semua agama punya konsep teologi tentang 'the others and the outsider'. Hal ini menempatkan "kafir" sebagai bentuk kriteria keyakinan dalam semua agama. Dengan demikian, secara umum penyebutan istilah "kafir" (sebagai bentuk tanda) dimaknai sebagai kriteria "yang lain" hanya dalam relasinya dengan keyakinan internal pada seluruh agama.

Ketiga, konsep kafir juga diwakili melalui kata "non-muslim" yang digunakan dalam konteks kebangsaan. Dikotomi antara non-muslim dan muslim sudah digunakan secara umum. Namun, menurutnya perlu kehati-hatian dalam menggunakannya di konteks sosial politik. Din menyatakan "[...] di masyarakat majemuk seperti Indonesia pemakaian istilah kafir untuk menyebut non-muslim harus dengan bijak dan hati-hati". Meskipun pemakaian istilah kafir selalu diasosiasikan dengan non-muslim, penggunaannya dalam konteks berbangsa harus dibarengi dengan sikap tasamuh (toleransi) sehingga pemakaian istilah tersebut tidak dipakai secara peyoratif (memperburuk) kepada orang lain. Pada aspek ini, konsep "kafir" tidak hanya digunakan melalui penyebutan nonmuslim saja, tapi juga dinilai cenderung digunakan untuk membedakan seseorang baik atau buruk. Ketika seseorang mendapat julukan "kafir", ia telah dicap buruk oleh orang lain.

Din menyebutkan, pemakaian istilah kafir harus sesuai dengan konteks seperti yang telah dijabarkan dalam kitab suci (Al Quran). Istilah tersebut selayaknya digunakan dalam konteks keagamaan dan kebangsaan secara hati-hati. Meskipun penyebutan "kafir" dinilai dapat mengarahkan pada "memperburuk orang lain", Din mengatakan tidak bersepakat untuk mengubah istilah "kafir". Upaya ini mengartikan, Din tetap menggunakan istilah tersebut karena punya keyakinan bahwa istilah tersebut tertulis dalam kitab suci. Penggunaannya harus hati-hati dan "tidak dengan 'gebyah uyah' kata kafir dihilangkan."

Dalam pandangan Nahdlatul Ulama, pemaknaan "kafir" dapat dilihat melalui beberapa penandaan yang diunggah. NU mengunggah ulang dari beberapa akun lain; Achmad Munjid, Nadirsyah Hosen, Quraisy Syihab, serta Netizen_NU. Unggahan tersebut berupa pernyataan, opini, serta tanggapan terhadap video lain. Konsep "kafir" digunakan dalam bentuk berbeda yang bentuk penggunaannya selalu diasosiasikan dengan agama, kebangsaan, politik, dan tindakan komunikasi.

Tabel 2 Konsep, bentuk, dan asosiasi penggunaan "kafir" oleh Nahdlatul Ulama

\begin{tabular}{|c|c|c|c|}
\hline \multicolumn{4}{|c|}{ Kafir } \\
\hline Signified & Signifier & $\begin{array}{l}\text { Relasi } \\
\text { asosiatif }\end{array}$ & Oposisi \\
\hline $\begin{array}{l}\text { Konsep } \\
\text { Kafir }\end{array}$ & $\begin{array}{l}\text { Muslim } \\
\text { belum tentu } \\
\text { mukmin; } \\
\text { kafir; } \\
\text { menutup } \\
\text { kebenaran } \\
\text { dan keesaan; } \\
\text { tidak }\end{array}$ & $\begin{array}{l}\text { (agama) } \\
\text { Kategori } \\
\text { muslim }\end{array}$ & $\begin{array}{l}\text { Muslim } \\
\text { pasti } \\
\text { mukmin, } \\
\text { non- } \\
\text { muslim, }\end{array}$ \\
\hline
\end{tabular}




\begin{tabular}{|c|c|c|}
\hline \multicolumn{3}{|l|}{ melakukan; } \\
\hline $\begin{array}{l}\text { Kafir dzimi, } \\
\text { kafir harbi }\end{array}$ & $\begin{array}{l}\text { (agama- } \\
\text { bangsa) } \\
\text { sistem } \\
\text { kenegaraan }\end{array}$ & $\begin{array}{l}\text { Modern, } \\
\text { Pancasila, } \\
\text { Warga } \\
\text { negara, } \\
\text { pembelot }\end{array}$ \\
\hline Warga asing & Politik & Muslim \\
\hline $\begin{array}{l}\text { Non-muslim, } \\
\text { warga } \\
\text { negara, } \\
\text { muwattinun. }\end{array}$ & $\begin{array}{l}\text { (kebangsaan) } \\
\text { Labeling }\end{array}$ & Kafir. \\
\hline Kufar, kufron & Komunikasi & Kafir \\
\hline
\end{tabular}

Beberapa bentuk bahasa yang mengacu pada konsep "kafir" dalam hubungannya dengan agama, dapat ditemukan melalui bentuk bahasa berbeda. Beberapa bentuk bahasa ini adalah muslim tidak satu paket, kafir, menutup kebenaran dan keesaan, warga negara, muwattin, dan bentuk lain. Kesemuanya digunakan untuk merujuk pada konsep "kafir" dengan asosiasi penggunaan yang dimaksudkan pada sistem internal dalam agama Islam.

Melalui quote Achmad Munjid, konsep "kafir" diwujudkan melalui muslim tidak satu paket, nonmuslim. Pernyataan Munjid tidak langsung merujuk pada pendefinisian kafir secara langsung. Kalimat berupa "muslim tidak satu paket" menandakan terdapat pembedaan dalam kategori muslim itu sendiri. Muslim dapat dibedakan dengan jenis muslim lain yakni mukmin. Jika muslim, belum tentu mukmin, tapi mukmin pasti muslim.

Selain itu, wujud konsep kafir dalam relasinya dengan teologi Islam juga dimunculkan NU melalui video dari Quraish Shihab. Dalam video tersebut, Quraish Shihab memaparkan sejumlah makna pada istilah "kafir" yang dapat menjadi penanda (signifier) bahwa seseorang disebut sebagai "kafir". Kafir dirujuk sebagai konsep yang didefinisikan sebagai seseorang yang (a) tidak percaya keesaan Allah, mengingkari Tauhid (menutupi kebenaran agama), (b) tidak tahu kebenaran agama (menutupi kebenaran karena tidak memiliki informasi), (c) tidak menjalankan perintah agama (melakukan pelanggaran agama), (d) menuduh orang lain kafir dan, (e) murtad atau non-muslim (keluar dari agama Islam). Dengan demikian, seseorang dikatakan sebagai 'bukan kafir' apabila ia mengetahui kebenaran agama, mempercayai keesaan Allah SWT, memahami perintah agama, menjalankan perintah agama, beragama Islam, dan tidak menuduh orang lain kafir. Apabila salah satu syarat 'bukan kafir' dilanggar, ia dapat dikatakan kafir mengacu kepada aturan agama.

Penyebutan seseorang sebagai kafir seolah harus memenuhi seluruh kriteria. Hal ini seolah mendorong pada keketatan dan kehati-hatian penyebutan "kafir" pada orang lain. Orang yang melakukan pelanggaran agama tidak serta merta ia disebut kafir. Apabila masih ada hal mengenai 'bukan kafir' masih melekat pada seseorang, ia tidak bisa dikatakan sebagai kafir walaupun beberapa syarat 'bukan kafir' telah dilanggar. Oleh karenanya, seseorang tidak diperkenankan menuduh orang lain kafir karena menganggap orang lain telah melanggar perintah agama.

Relasi internal muslim-mukmin dan kafir-non muslim tersebut selanjutnya digunakan untuk membangun penandaan lain pada kafir dan nonmuslim. Melalui kalimat "Seorang non muslim tidak dengan sendirinya kafir", NU berusaha memperluas acuan "kafir" tidak hanya pada system pemaknaan dalam Islam. Kafir dan NonMuslim hanya dapat dimunculkan melalui perantara kebangsaan. Oleh karena itu, melalui penggunaan kata kerja "tidak digunakan", konsep kafir saat dihubungkan dengan konteks kebangsaan, "kafir" sebaiknya tidak digunakan untuk menyebut non-muslim. Terdapat dua system berbeda yang digunakan untuk menggunakan "kafir" di sini, yakni dalam konteks beragama (muslim dan mukmin) dan konteks berbangsa-bernegara (non-muslim). 


\section{b. Konteks Penggunaan: Antara Akidah- teologis, Kebangsaan, dan Politik}

Aturan baku mengenai penggunaan "kafir" dalam konteks Islam secara rinci ada di dalam Al Quran. Akan tetapi, tafsir mengenai istilah "kafir" dalam Al Quran pun masih sering menjadi perdebatan. Secara harfiah, kata "kafir" berasal dari bahasa Arab yang artinya kafara-yakfurukufran-kufuran-kufranan yang artinya menyembunyikan atau menutupi, menyembunyikan sesuatu yang bermanfaat, tidak berterimakasih (atas nikmat Allah) (Saleh, 2018). Kaidah bahasa (langue) menempati posisi kunci dalam tradisi semiotika structural. Tapi, kaidah tersebut selalu dipraktikkan dalam berbagai macam bentuk tanda berdasarkan kode produksi tanda.

Muhammadiyah melalui pernyataan Din Syamsudin, menggunakan "kafir" melalui berbagai wujud tanda yang dihubungkan dengan aspek teologis, negara, dan juga politik. Kafir dapat digunakan sebagai istilah untuk memberikan 'label' buruk kepada seseorang yang bisa mendegradasi harkat dan martabat manusia. Hal ini dapat terlihat dari perbuatan mengucapkan ujaran kebencian kepada lawan politik atau memberikan sematan nama binatang pada kelompok tertentu.

Tabel 3 Language, parole, \& code

\begin{tabular}{lll}
\hline Langue & Parole & Kode \\
\hline Kafir & Makna peyoratif, & Politik \\
dalam & Ujaran & \\
kitab & kebencian, politik & \\
\cline { 2 - 3 } suci & Penggunaan bijak & Teologis \\
& dan hati-hati - & \\
& "gebyah uyah" \\
& dihilangkan & \\
\hline
\end{tabular}

Sumber: Hasil olahan peneliti

Lebih luas lagi, Din Syamsudin mengaitkan penggunaan istilah "kafir" dengan situasi sosial politik yang sedang terjadi di Indonesia. Berita tersebut terbit pada 3 Maret 2019, yakni masa menjelang Pemilihan Umum Presiden pada April
2019. Din Syamsudin pun menganggap bahwa penggunaan istilah "kafir" ada kaitannya dengan konteks Pilpres 2019. Selain itu, Din juga memberikan makna pada "kafir" sebagai tanggapan pada Munas NU yang menghasilkan fatwa penggantian penggunaan "kafir" dalam konteks kenegaraan.

"[...] putusan dari Munas NU sifatnya hanya sebagai fatwa. Karena ini sifatnya fatwa, maka tidak wajib diikuti. Mengingat fatwa tersebut sudah tersebar secara luas, pasti akan menimbulkan polemik. Terlebih ada event politik, hal semacam ini akan dengan sangat mudah menyulut ketegangan sampai akhirnya menimbulkan ujaran kebencian kepada yang mereka anggap sebagai lawan politiknya.".

Din Syamsudin menganggap bahwa fatwa Munas NU memungkinkan untuk menimbulkan ketegangan menjelang Pilpres. Hal ini ditandai dengan adanya ujaran kebencian kepada lawan politik. Perlu diketahui bahwa Munas NU tersebut membahas mengenai status nonmuslim dalam konteks bermasyarakat dan bernegara ${ }^{1}$. Akan tetapi, Din Syamsudin memahami konteks pembahasan Munas NU tersebut dengan penyematan istilah "kafir" pada seseorang yang dapat menimbulkan ketegangan politik sebab Munas NU yang dilaksanakan menjelang Pemilu Presiden 2019.

Tidak berhenti di situ, Din Syamsudin juga menyebut bahwa menjelang Pilpres 2019 ujaran kebencian sudah muncul. "Menuju Pilpres mendatang sudah ada ujaran kebencian dengan menyematkan nama binatang kepada kelompok satu ke kelompok lainnya. Hemat saya itu tidak etis, itu sama saja mendegradasi harkat martabat kemanusiaan." Pernyataan ini masih senada dengan pernyataan sebelumnya yang mengatakan menjelang Pilpres 2019 mulai

\footnotetext{
${ }^{1}$ http://www.nu.or.id/post/read/103272/penjelasanperumus-bahtsul-masail-munas-nu-soal-polemik-kafir
} 
timbul ujaran-ujaran kebencian. Mengenai pernyataan 'mendegradasi harkat dan martabat manusia', hal ini sejalan dengan pesan Din Syamsudin agar penggunaan istilah "kafir" 'tidak dipakai secara peyoratif (memperburuk) kepada orang lain'.

Nahdlatul Ulama menggunakan "kafir" dalam berbagai konteks penggunaanya. Kafir sebagai tanda, mengacu pada konsep yang terdapat pada Alquran, hadits dan kitab tafsir. Definisi ini mencakup: Orang yang tertutup dari ajaran agama, muslim yang tidak mukmin. Kesepakatan makna acuan pada tanda "kafir" ini hanya dapat dipahami dalam dengan menghubungkan pada kode atau sistem tanda penggunaannya. Setidaknya, terdapat beberapa kode penggunaan tanda yang dipakai oleh Nahdlatul Ulama: teologi keagamaan, kebangsaan, dan politik.

Tabel 4 Language, parole, \& code

\begin{tabular}{lll}
\hline Langue & Parole & Kode \\
\hline Kafir & Mengetahui & Teologis \\
dalam & keesaan Tuhan dan & \\
kitab & Nabi; $\quad$ tidak & \\
suci, & beriman, $99 \%$ & \\
Hadits, & melanggar agama; \\
dan & penyebutan kafir \\
Tafsir & adalah hak tuhan; \\
\cline { 2 - 3 } & Warga negara; & Teologis \\
& non-muslim; & \\
& muwattin & \\
\hline & Warga negara & Politik \\
& asing & \\
\hline & Sumber: Hasil olahan peneliti
\end{tabular}

Istilah "kafir" untuk menyebut muslim yang tidak mu'min sesuai dengan acuan dalam ketentuan di Al Quran, yakni kafir dalam arti mengetahui keesaan Tuhan dan Nabi Muhammad sebagai utusanNya tetapi ia menolak mengakuinya. Dalam praktiknya (parole), NU juga menggunakan konsep "kafir" untuk membahasakan orang yang tidak beriman, tidak menjalankan perintah agama. Hal ini menunjukkan, penggunaannya dalam konteks akidah tetap digunakan dan tidak boleh diganti. Hal ini diwujudkan melalui kalimat "Istilah kafir dalam bahasan akidah tidak disinggung dan tidak dikotak-katik" sebagaimana diungkapkan oleh Nadirsyah Hosen.

Quraish Shihab juga mengacu kepada hadist nabi dan tafsir dari tokoh otoritatif, Imam Ghazali. Menurutnya, tuduhan kafir pada orang lain dapat kembali pada penuduh; bahkan oleh Tuhan ia dianggap sebagai kafir. Pendapat Imam Ghazali juga dikutip sebagai cara mewujudkan konsep kafir dalam kode teologis. Quraish Shihab mengatakan "Imam Ghazali mengingatkan, kalau ada satu orang melakukan pelanggaran agama sudah terbukti $99 \%$ ia melanggar agama, jangan dulu cap dia sebagai kafir kalau belum sempurna 100\%".

$\mathrm{Hal}$ ini sekaligus menekankan bahwa penyebutan kafir kepada manusia bukanlah hak manusia, melainkan hak Tuhan. Sekalipun seseorang tersebut diduga keluar dari agama, manusia tidak memiliki hak untuk melabeli seseorang itu sebagai "kafir". Pada titik ini, konsep kafir dihubungkan dengan fenomena kecenderungan seseorang dengan mudahnya mengkafirkan orang lain tanpa ada acuan yang jelas. Pemaknaan "kafir" oleh Quraish Shihab mengacu pada aturan bakunya, yakni aturan agama. Ini menandakan bahwa secara akidah (sistem teologis internal), berbagai penandaan yang mengacu pada konsep kafir dapat diwujudkan melalui berbagai penyebutan dan hanya dapat dipahami melalui kode keagamaan, bukan dengan yang lain.

Dalam konteks kebangsaan, istilah "kafir" dipakai secara berbeda. Kafir tidak hanya diartikan secara literal dalam sistem bahasa Arab (kafaro-yakfuru-kufron). Achmad Munjid berusaha menghilangkan penyematan istilah kafir kepada mereka yang non-muslim. Sebab, ia menyakini bahwa istilah "[...]"kafir" tidak seharusnya digunakan [...] dalam konteks berbangsa dan bernegara, setiap warga negara 
bekedudukan sederajat". Dalam hal ini, secara implisit Achmad Munjid menyatakan bahwa penyematan istilah "kafir" pada seseorang cenderung membuat derajat orang tersebut menjadi tidak setara dengan yang lain. Seolaholah mereka yang "kafir" lebih rendah dibandingkan dengan mereka yang bukan kafir. Oleh karenanya, ia berpendapat agar istilah "kafir" dalam konteks berbangsa dan bernegara dihilangkan sebab derajat tiap orang atau warga negara dalam konteks kehidupan berbangsa dan bernegara dianggap setara.

Nadirsyah Hosen memperluasnya dengan pendekatan modern, yaitu konsep negarabangsa. Acuan "kafir" yang berubah dari nonmuslim menjadi warga negara bukan tanpa alasan. Nadirsyah Hosen menggunakan konsep kafir melalui penyebutan "non-muslim" dalam konteks sistem kenegaraan. Penggunaanya dikaitkan dengan orang yang hidup berdampingan dengan umat Islam dalam suatu negara. Penggunaan "non-muslim" sebagai acuan konsep kafir ini didasarkan gugus tanda dalam kalimat "tidak membahas istilah kafir dalam iman atau akidah". Akidah adalah salah satu pembahasan dalam Alquran mengenai keimanan. Artinya, "kafir" dalam konteks akidah diacu kepada mereka yang berbeda keyakinan atau seseorang dengan agama selain Islam. Nadirsyah Hosen secara spesifik menyatakan bahwa "kafir" adalah non-muslim, akan tetapi ia menggantinya dengan istilah warga negara sebab membahasnya dalam konteks kehidupan berbangsa dan bernegara.

Acuan "kafir" yang berubah dari non-muslim menjadi warga negara bukan tanpa alasan. Nadirsyah sempat mengatakan "konsep keimanan jangan dicampuradukkan dengan konsep bernegara. Setiap negara berhak menentukan wilayah dan warga negara masingmasing". Artinya, ada kecenderungan pemisahan antara urusan keimanan dan urusan bernegara. Keimanan berkaitan erat dengan kepercayaan seseorang tentang suatu ajaran agama, sedangkan negara berkaitan erat dengan kepentingan orang banyak dalam suatu wilayah tertentu. Artinya, mengacu pada pernyataan Nadirsyah, konsep keimanan dan konsep bernegara memiliki konteks yang berbeda dan tidak bisa disatukan. Oleh karenanya, Nadirsyah menyepakati istilah "kafir" diganti dengan istilah "warga negara" dalam konteks bernegara. Sedangkan, acuan "kafir" dalam konteks keimanan - seseorang yang berbeda keyakinan atau keimanan - tetap disepakati, tetapi tidak digunakan ketika memasuki ranah konsep bernegara.

Artinya, ada kecenderungan pemisahan antara penggunaan "kafir" sebagai tanda dalam aspek keimanan dan urusan bernegara. Keimanan berkaitan erat dengan kepercayaan seseorang tentang suatu ajaran agama, sedangkan negara berkaitan erat dengan kepentingan orang banyak dalam suatu wilayah tertentu.

Mengenai penggunaan kafir yang diubah dengan istilah warga negara, Nadirsyah menjelaskan bahwa hal tersebut adalah "konsekuensi dalam menerima konsep negarabangsa, kita juga harus menerima konsep warga negara. Semua warga negara dipandang memiliki hak dan kewajiban yang sama". Kemudian, pernyataan itu dilanjutkan dengan "kita lihat saja Undang-Undang Dasar (UUD) 1945, tidak ada pembagian rakyat ke dalam kategori kafir atau muslim. Begitu pula hak dan kewajiban tidak dibedakan. Yang ada malah jaminan konstitusi untuk semua umat beragama beribadah sesuai dengan agama masing-masing." Kedua pernyataan tersebut menekankan bahwa ada kecenderungan kafir dalam konteks beragama dipandang tidak setara dengan yang bukan kafir. Akan tetapi, dalam konsep negarabangsa, siapapun ia - tanpa memandang status keagamaan - memiliki hak dan kewajiban yang sama sebagai warga negara dan hal itu dijamin 
oleh negara dalam konstitusi UUD 1945. Dengan begitu, penggunaan istilah "kafir" dalam konsep negara-bangsa versi Nadirsyah Hosen mengacu pada warga negara, tidak hanya pada muslim. Akan tetapi, dalam praktiknya kata "kafir" itu hilang dan diganti dengan kata "warga negara" yang cenderung lebih universal dan juga mencakup muslim itu sendiri. Dengan begitu, leburlah dikotomi kafir-muslim dalam konsep warga negara. Nadirsyah Hosen pun sempat mengaitkan kafir dengan khilafah. la beranggapan bahwa istilah "kafir" dan "khilafah" merupakan istilah masa lampau. "Kafir" sebagai konsep acuan, dirupakan melalui bahasa ketimpangan literatur figh dan perkembangan negara modern. Penggunaan istilah "kafir" dalam hal ini, dimaknai sebagai konsep yang berubah dan mengalami perluasan penggunaan dalam konsep dunia modern. Melalui dikotomi klasikmodern, Nadirsyah berupaya untuk menekankan penggunaan konsep kafir yang juga harus berubah. Orang "kafir" pada masa Khilafah (klasik) cenderung memiliki derajat rendah dalam konteks agama dan diperlakukan kurang pantas dalam konteks sosial (modern).

Pada penggunaannya yang lain, "kafir" seolah-olah mengarah pada bentuk keterpaksaan dalam memeluk Islam dengan dalih agar diperlakukan pantas (tidak dilecehkan) oleh orang muslim. "Pelecehan" digunakan sebagai tanda yang dihubungkan dengan kondisi terpaksa untuk meyakini sesuatu. Hal ini seolah mengarah pada bentuk diskriminasi pada kelompok minoritas. Oleh sebab itu, Nadirsyah menekankan untuk mengganti istilah "kafir" dengan warga negara agar ketimpangan seperti yang disebutkan dalam pernyataannya tidak terjadi di masa kini. Negara justru menjamin kebebasan memeluk agama dan seaman derajat hak dan kewajiban dalam Undang-Undang Dasar 1945 .

Nadirsyah lebih lanjut mengatakan bahwa ada kesalahpahaman dalam memaknai Munas
NU. Jika merujuk pada pernyataan Nadirsyah, Munas NU semata-mata membahas non-mulim dalam konteks berbangsa dan bernegara, Penyebutan "kafir" bahkan juga dihubungkan dengan politik sebagai kode yang dapat mengubah maknanya. Tidak hanya "kafir-non muslim" dalam konteks teologis keagamaan, tapi juga dapat digunakan dalam relasinya dengan politik. Beberapa tanda lain yang digunakan dalam kode produksi sistem politik ini adalah warga negara asing, hoax, liberal, dan pilpres. Penandaan tersebut digunakan untuk menjelaskan konteks Fatwa NU 2019 yang berisi himbauan penggantian penyebutan "kafir" dengan "muwattin atau warga negara" dalam kehidupan berbangsa dan politik.

\section{c. Memaknai Konstruksi dan Narasi "Kafir"}

Konstruksi kafir dapat dilihat melalui penggunaannya dalam tata bahasa (paradigmatik) dapat diteruskan untuk menganalisa menyeluruh pada teks (sintagmatik) tentang narasi makna kafir. Muhammadiyah melalui pendapat Din Syamsudin menyatakaan kafir dengan merujuk pada kata benda yakni: (a) seorang non-muslim. Din Syamsudin sepakat menyebut non-muslim sebagai kafir, akan tetapi penyebutan nonmuslim sebagai kafir tidak dapat dilakukan secara sewenang-wenang. Ada acuan lain yang bisa sebagai indikator seseorang disebut sebagai "kafir" sebagaimana yang telah dikatakan oleh Din Syamsudin. (b) Seseorang yang tidak beriman sesuai dengan ajaran Islam; kafir, musyrik, dan fasik. Acuan "kafir" pada seseorang yang tidak beriman ini sesuai dengan aturan baku yang terdapat dalam Alquran sendiri yakni Surah Al-Kafirun yang artinya orang-orang kafir (orang yang tidak beriman). 
Tabel 5 Aspek synchronic dan diachronic dalam teks

\begin{tabular}{|l|}
\hline Asynchronic analysis (Paradigmatik) \\
\hline Kafir untuk menyebut non-muslim \\
\hline Ada yang tidak beriman sesuai Islam disebut oleh Al Qur'an dengan kata kafir \\
\hline $\begin{array}{l}\text { Istilah tersebut juga ada di agama selain Islam dalam menyebut orang yang berbeda dalam keimanan dengan } \\
\text { mereka }\end{array}$ \\
\hline \begin{tabular}{l} 
Pemakaian istilah tersebut tidak dipakai secara peyoratif (memperburuk) kepada orang lain \\
\hline $\begin{array}{l}\text { Ujaran kebencian kepada yang mereka anggap sebagai lawan politiknya } \\
\text { saya itu tidak etis, itu sama saja mendegradasi harkat martabat kemanusiaan }\end{array}$ \\
\hline $\begin{array}{l}\text { Sintagmatik } \\
\text { (diacronic analysis) }\end{array}$
\end{tabular} $\begin{array}{l}\text { Akidah } \\
\text { Teologi keagamaan } \\
\text { Toleransi } \\
\text { Politik }\end{array}$ \\
\hline
\end{tabular}

Sumber: Hasil olahan peneliti

Selain itu, Din Syamsudin juga mengacu kepada (c) seseorang yang berbeda keyakinan atau keimanan dalam teologi tertentu. Acuan ini senada dengan acuan sebelumnya yakni non-muslim. Akan tetapi, Din Syamsudin juga menekankan bahwa seorang muslim dapat disebut sebagai "kafir" dari sudut pandang agama lain. Din Syamsudin mengatakan "[...] istilah tersebut (kafir = pen) perlu dipahami secara menyeluruh, karena pemakaian istilah seperti itu bukan hanya ada di Islam tapi juga agama yang lain. [...] Istilah tersebut juga ada di agama selain Islam dalam menyebut orang yang berbeda dalam keimanan dengan mereka.".

Selain itu, penggunaan istilah kafir juga merujuk pada perilaku tertentu yang dapat menjadikan seseorang disebut secara tidak langsung sebagai "kafir", diantaranya: (a) perilaku yang merendahkan orang lain. Hal ini diucapkan oleh Din Syamsudin melihat kecenderungan penggunaan istilah "kafir" yang menimbulkan perbedaan strata atau kelas sosial di masyarakat, mereka yang kafir dicap buruk dan non-kafir dicap baik. Din Syamsudin menyatakan "Dalam konteks berbangsa memang harus dibarengi dengan sikap tasamuh (toleransi), sehingga pemakaian istilah tersebut tidak dipakai secara peyoratif (memperburuk) kepada orang lain. Pernyataan ini menekankan bahwa penggunaan istilah "kafir" yang sewenang-wenang berpotensi untuk merendahkan orang lain. Din Syamsudin juga mengaitkan penggunaan istilah kafir dengan konteks Pemilu Presiden 2019, bahwa kafir diacu pada (b) mengucapkan ujaran kebencian. la menganggap bahwa istilah "kafir" seringkali disematkan kepada mereka yang merupakan lawan politik sebagai bentuk ujaran kebencian. Pernyataan tersebut membuktikan bahwa kafir digunakan untuk menyebut lawan politik, apabila seseorang tidak mendukung pasangan calon tertentu ia akan disebut sebagai "kafir". 
Susunan penandaan yang ada pada kata dan kalimat ini tidak dapat dimaknai terpisah dengan bentuk penandaan "kafir" pada kalimat yang lain. Secara sintagmatik, penggunaan kata "kafir" oleh Muhammadiyah tidak hanya diasosiasikan pada agama, tapi juga dihubungkan dengan kebangsaan, politik, teologi keagamaan, dan toleransi.

Penggunaan kata "kafir" oleh Muhammadiyah melalui pernyataan Din Syamsuddin memberikan narasi pada pembaca bahwa kafir tidak hanya digunakan dalam perspektif tunggal keagamaan. Kafir diasosiasikan pada konteks politik mengarahkan penggunaannya pada kehati-hatian. Hal ini karena penggunaannya dapat diarahkan untuk menghujat dan merendahkan martabat orang lain.

Makna Kafir menurut Nahdlatul Ulama, tidak hanya didapatkan dari satu tatanan tanda, tapi dari beberapa tatanan tanda dalam satu pernyataan yang sama. Setiap susunan unsur kalimat (sintagmatik) yang diutarakan oleh Achmad Munjid secara eksplisit menyatakan penyebutan istilah "kafir" berfokus pada karakteristik seseorang yang memungkinkan ia disebut sebagai "kafir", yakni pada level sintagmatik di antaranya; (a) seseorang beragama Islam yang bukan mu'min pada kalimat "Seorang muslim belum tentu mu'min. Seorang non muslim tidak dengan sendirinya kafir". Ini juga menegaskan ada potensi muslim disebut sebagai "kafir" jika tidak mengakui keesaan Allah dan Nabi Muhammad sebagai utusanNya. (b) Seorang warga negara non-muslim. "Kafir" yang diasosiasikan dengan non-muslim diganti dengan istilah "warga negara". Dengan demikian, non muslim memiliki kesamaan derajat dengan muslim dalam konteks berbangsa dan bernegara melalui konsep warga negara. Berbeda dalam konteks agama, di mana ada perbedaan derajat dalam hal keimanan antara "kafir" dan "bukan kafir".

Konstruksi "kafir" dalam struktur kalimat (sintagmatik) pernyataan Nadirsyah Hosen berfokus pada kategori kata benda (paradigmatik). Beberapa diantaranya adalah (a) orang-orang kafir atau yang tidak beriman dan (b) warga negara non-muslim. Orang-orang kafir ini diacu pada pernyataanya "Tidak benar gorengan sebagian pihak seolah ulama NU hendak menghapus surah Al Kafirun dalam Alquran". Artinya, Nadirsyah tetap mengacu pada aturan baku yakni Alquran untuk menyebut orang kafir sebagai seseorang yang tidak beriman. Akan tetapi, ia tidak sepakat jika kata "kafir" disematkan kepada non-muslim dalam konteks berbangsa dan bernegara. Oleh karenanya, ia mengganti istilah "kafir" dengan warga negara. Dengan demikian, konsep warga negara sekaligus menghilangkan dikotomi kafir-muslim. Leburnya kafir dan muslim dalam konteks berbangsa dan bernegara didasarkan pada acuan Undang-Undang Dasar 1945 yang menjamin kesederajatan hak dan kewajiban serta kebebasan beragama bagi setiap warga negara.

Dari segi struktur kalimat, pendapat Quraish Shihab lebih menekankan makna kafir pada level perilaku atau kata kerja. Beberapa diantaranya dibuktikan dengan pemakaian kata menutupi kebenaran, melakukan pelanggaran agama, menuduh orang lain kafir, dan kelvar dari agama. Struktur kalimat tersebut menunjukkan bahwa seseorang dapat dikatakan sebagai kafir dapat dilihat dari perilaku, perbuatan atau tindakan yang dilakukannya. Tentunya, pemaknaan ini tidak terlepas dari acuan yang dipakai oleh Quraish Shihab, yakni aturan agama yang menekankan pada pengertian kafir yang 
diartikan 'menyembunyikan' atau 'menutupi'. Selain itu, acuan pendapat Imam Ghazali juga menekankan pada perbuatan, yakni "melakukan pelanggaran agama". Begitu pun dengan acuan hadist nabi mengacu pada perilaku "menuduh orang lain kafir" dalam arti "keluar dari agama" untuk menyebut seseorang sebagai kafir.

\section{Kesimpulan}

Muhammadiyah dan Nahdlatul Ulama (NU) menggunakan "kafir" yang mengacu pada konsep kafir dalam agama Islam. Bentuk penandaan (signifier) yang digunakan untuk konsep kafir (signified) di antaranya adalah kafir, non-muslim, warga negara, muwattin, dzimmi-harbi. Baik NU dan Muhammadiyah sama-sama menggunakannya dengan kode produksi tanda yang sama, yaitu teologis keagamaan, kebangsaan, dan politik. Akan tetapi, narasi penggunaan kafir dikonstruksi secara berbeda oleh NU dan Muhammadiyah.

NU menyepakati bahwa terdapat dua konteks yang berbeda dalam penggunaan istilah "kafir". Istilah "kafir" dalam konteks keimanan (agama) yang merujuk kepada non-muslim (seseorang dengan keimanan dan keyakinan yang berbeda) tidak tepat digunakan dalam konteks bernegara. NU menyatakan bahwa dalam kehidupan berbangsa dan bernegara istilah "kafir" tidak dapat serta merta digunakan untuk menyebut non-muslim karena terdapat potensi penilaian derajat yang lebih rendah. Oleh karena itu, NU merekomendasikan untuk menghilangkan penggunaan istilah "kafir" bagi nonmuslim dan menggantinya dengan istilah 'muwathinun' (warga negara) dalam konteks kehidupan berbangsa dan bernegara.
Berbeda dengan NU, Muhammadiyah menekankan bahwa penggunaan istilah "kafir" memiliki kecenderungan merujuk kepada non-muslim, seseorang beragama Islam yang tidak beriman sesuai ajaran Islam, serta seseorang yang berbeda keyakinan. Muhammadiyah menambahkan istilah "kafir" tidak boleh dihilangkan dalam ajaran Islam, namun penyebutan "kafir" perlu digunakan secara bijak. Komunikasi dalam konteks berbangsa dan bernegara harus disertai dengan toleransi, sehingga istilah "kafir" tidak digunakan untuk merendahkan orang lain. Muhammadiyah menjelaskan bahwa penggunaan istilah "kafir" yang terjadi di Indonesia pada masa menjelang Pemilihan Umum Presiden tahun 2019, memiliki kaitan dengan situasi sosial politik. Istilah "kafir" digunakan sebagai ujaran kebencian, yang digunakan untuk menyebut mereka yang menjadi lawan politik (tidak mendukung pasangan calon tertentu yang sama).

Berdasarkan hasil riset yang telah dipaparkan, riset ini terbatas pada data dokumentasi di media sosial twitter dari kedua akun resmi NU dan Muhammadiyah terkait perbincangan penggunaan istilah "kafir". Riset selanjutnya dapat menggali pemaknaan anggota dan/atau follower kedua organisasi Islam di Indonesia tersebut mengenai unggahan terkait penggunaan istilah "kafir" atau istilah lain yang sering digunakan dalam situasi dan konteks sosial politik. Selain itu, riset selanjutnya juga dapat menelusuri pembingkaian pesan yang diunggah di media sosial atau website dengan topik yang mendorong dan menghadirkan diskusi atau perbincangan publik untuk menemukan sikap dari kedua organisasi Islam ini dalam merespon topik terkait dalam situasi sosial dan politik tertentu. Sebagai tindak lanjut dari riset ini, periset 
selanjutnya dapat mengeksplor persepsi, sikap, pemaknaan, dan penerimaan warga negara (baik muslim maupun non-muslim) atas penggunaan istilah kafir.

\section{Referensi}

Adam, A. (2017, January 13). Intoleransi Masih Tinggi, Terbanyak di Jawa Barat - Tirto.ID. Retrieved from https://tirto.id/intoleransi-masihtinggi-terbanyak-di-jawa-barat-cgSE

Ahmad, Amar. (2013). Perkembangan Media Online dan Fenomena Disinformasi (Analisis pada Sejumlah Situs Islam). Jurnal Pekommas, (Volume 16, No.3): 177-186.

Ahyar, M. (2017). Islamic Clicktivism: Internet, Democracy and Contemporary Islamist Activism in Surakarta. Studia Islamika, Vol. 24, No. 3, 2017 DOI: 10.15408/sdi.v24i3.4859

Ali, M. S. (2017). Sejarah Singkat Nahdlatul Ulama - Islami[dot]co. Retrieved March 17, 2019, from https://islami.co/sejarah-singkatnahdlatul-ulama/

Carr, C. T., \& Hayes, R. A. (2015). Social Media: Defining, Developing, and Divining. Atlantic Journal of Communication, 23(1), 46-65. https://doi.org/10.1080/15456870. 2015.972282

Chandler, Daniel. (2002). Semiotics: The Basics. New York: Routledge.

Croteau, David dan William Hoynes. (2000). Media/ Society: Industries, Images and Audiences. California: Pine Forge Press.

Kriyantono, R. (2014). Teori public relations perspektif barat dan lokal: Aplikasi riset \& praktis. Jakarta: Prenada
LIPI. (2018). LIPI Ungkap Fenomena Sosial Intoleransi dan Radikalisme. Retrieved April 15, 2019, from http://lipi.go.id/siaranpress/lipiungkap-fenomena-sosialintoleransi-dan-radikalisme/21357

Lister Martin dkk. (2009). New Media: a Critical Introduction, 2nd edition. London: Routledge.

Littlejohn, S., \& Foss, K. (2009). Encyclopedia of Communication Theory. (S. W. Littlejohn \& K. A. Foss, Eds.). Los Angeles, Calif: Sage. https://doi.org/10.4135/97814129 59384

Maarif, A. S. (2006). Islam dan Pancasila sebagai Dasar Negara: Studi tentang Perdebatan dalam Konstituante. Jakarta: Pustaka LP3S Indonesia.

Matan Keyakinan dan Cita-cita Hidup Muhammadiyah | Pimpinan Pusat Muhammadiyah. (1997). Retrieved March 17, 2019, from http://www.muhammadiyah.or.id/ id/content-175-det-matankeyakinan-dan-citacita-hidup.html

Maulana, D. (2017). The Exclusivism of Religion Teachers: Intolerance and Radicalism in Indonesian Public Schools. Studia Islamika, Vol. 24, No. 2, $2017 . \quad$ DOI: 10.15408/sdi.v24i2.5707

McQuail, Denis. (2011). Teori Komunikasi Massa McQuail, Edisi 6 Buku 1. Jakarta: Salemba Humanika.

Milenial "mudah" terpapar radikalisme karena situs organisasi Islam moderat "kalah renyah"? - BBC News Indonesia. (2019). Retrieved April 14, 2019, from https://www.bbc.com/indonesia/i ndonesia-47308385 
Muhammadiyah. (2019). Terkait Polemik Penghapusan Istilah Kafir, Berikut Tanggapan Din Syamsuddin - Berita I Pimpinan Pusat Muhammadiyah. Retrieved April 15, 2019, from http://www.muhammadiyah.or.id/ id/news-16100-detail-terkaitpolemik-penghapusan-istilah-kafirberikut-tanggapan-dinsyamsuddin.html

NU Online | Suara Nahdlatul Ulama. (2015). Retrieved March 17, 2019, from

http://www.nu.or.id/about/paham +keagamaan

Rachman, D. A. (2019, March 31). Setara Institute: 2018, 202 Pelanggaran Kebebasan Beragama dan Berkeyakinan Terjadi Halaman all Kompas.com. Retrieved from https://nasional.kompas.com/read/2 019/03/31/16014091/setarainstitute-2018-202-pelanggarankebebasan-beragama-danberkeyakinan?page=all

Raditya, I. N. (2019). Sejarah Hari Lahir Nahdlatul Ulama (NU) 1926-2019 Tirto.ID. Retrieved March 17, 2019, from https://tirto.id/sejarah-harilahir-nahdlatul-ulama--nu--19262019-dfwj

Saroh, M. (2017). Survei: Pesan Intoleransi Bertebaran di Media Sosial Tirto.ID. Retrieved April 14, 2019, from https://tirto.id/survei-pesanintoleransi-bertebaran-di-mediasosial-cfeY

Saussure, F. (1959). Course in General Linguistics. N.Y.: McGraw Hill.

Straubhaaar, Joseph, Robert LaRose dan Lucinda Davenport. (2012). Media Now: Understanding Media, Culture and Technology (Seventh Edition). Boston: Wadsworth.
Strozier, R. (2012). Saussure, Derrida, and the Metaphysics of Subjectivity. Berlin, Boston: De Gruyter Mouton. Retrieved 01 Feb. 2020, from https://www.degruyter.com

Suaedy, A. (2009). Perspektif Pesantren: Islam Indonesia Gerakan Sosial Baru Demokratisasi. (A. M. Dja'far, Ed.). Jakarta: The Wahid Institute.

Tanjung, A., \& Muiz. (2019). Indonesia Beranekaragam, Islam Harus Jadi Rahmatan lil Alamin | NU Online. Retrieved March 17, 2019, from http://www.nu.or.id/post/read/10 3633/indonesia-beranekaragamislam-harus-jadi-rahmatan-lilalamin-

Treem, J. W., \& Leonardi, P. M. (2013). Social Media Use in Organizations: Exploring the Affordances of Visibility, Editability, Persistence, and Association. Annals of the International Communication Association, 36(1), 143-189. https://doi.org/10.1080/23808985. 2013.11679130

Van Bruinessen, M. (2002). Genealogies of Islamic radicalism in post-Suharto Indonesia. South East Asia Research, 10 (2), 117-154.

Vedi R. Hadiz (2008): Towards a Sociological Understanding of Islamic Radicalism in Indonesia, Journal of Contemporary Asia, 38:4, 638-647

Wahid, A. Destitry, N.A., Rakhmawati, F.Y. (2020). Radikalisme Di Media Sosial: Penyebutan Dan Konteks Sosial Penggunaannya. Jurnal InterAct, 9(1).

Wahid, A. (2020). Persepsi "Kafir" pada Muslim dan Non-Muslim: Konteks, Penggunaan, dan Komunikasi Partisipatif. Tuturlogi: Journal of Southeast Asian Communication, 1(2), 79-92. Retrieved 
from https://tuturlogi.ub.ac.id/index.

php/tuturlogi/article/view/39 